\title{
The oil nouveau-riche and arms imports
}

\author{
Pierre-Louis Vézina ${ }^{\dagger}$
}

March 16, 2020

\begin{abstract}
Countries that strike it rich when exploring for oil and gas often fail to see growth materialize. This paper shows that one way things can go awry is via squandering new wealth, based on future resource revenues, on arms imports. In the five years following a giant oil or gas discovery, arms imports increase by $25 \%$. The effect is even larger, i.e. $51 \%$, when the oil price is high, i.e./ $\$ 80$ per barrel and up. These estimates can be interpreted causally as the timing of giant oil discoveries is unpredictable due to the uncertain nature of exploration.
\end{abstract}

JEL CODES: F14, Q33

Key Words: giant discoveries, arms trade, resource curse.

${ }^{*}$ I am grateful to Jim Cust, Pierre Mandon, Kostas Matakos, Rick van der Ploeg, Michael Ross, Wessel Vermeulen, and participants at the 2019 World Bank-OxCarre workshop on extractives in Africa for excellent suggestions. This work is part of the World Bank's project on Africa's Resource future.

${ }^{\dagger}$ Dept of Political Economy, King’s College London. Email: pierre-louis.vezina@kcl.ac.uk. 


\section{INTRODUCTION}

Natural resources are often thought of as a curse, slowing long-run growth in developing countries (Sachs and Warner, 2001; van der Ploeg, 2011; Ross, 2012). Recent studies have also emphasized that resource discoveries themselves can have consequences, before windfalls start pouring in. This is because the prospect of resource wealth can stimulate the business cycle (Arezki et al., 2017) but also unleash malign political forces (Venables, 2016). Arezki et al. (2017) suggest that on average across countries investment increases right after a large and unexpected oil or gas discovery. This boosts GDP and nightlight intensity in cities (Smith and Wills, 2018), yet growth expectations tend to be too optimistic and disappointments or even reversals often follow (Cust and Mihalyi, 2017). This may be because internal armed conflicts emerge as a results of the newfound wealth (Lei and Michaels, 2014), or coups happen (Nordvik, 2018), or democratic institutions deteriorate (Tsui, 2011) and public money is not spent wisely. This brings us to the question this paper aims to answer: Do newly-oil-rich countries lash out on weapon imports? ${ }^{1}$

While newly oil-rich countries may buy weapons to protect their resources from rebels or foreign invasion, lashing out on weapon imports might turn out as anti-development for at least three reasons. ${ }^{2}$ One is that weapons cause conflicts, being one of its necessary technology (Hirshleifer, 2000). Pamp et al. (2018) for example shows that arms imports increase the probability of civil wars in conflict-prone countries, and hence suggests that arms spark escalation rather than act as a deterrent against conflicts. Similarly, Craft and Smaldone (2002) showed that arms imports predict civil wars in sub-Saharan Africa, and Wezeman et al. (2011) suggest that governments often can not secure their stockpiles and weapons are stolen by rebel groups. Another reason is that arms imports may lead to political

\footnotetext{
${ }^{1}$ Previous research suggests that military spending in general increases following discoveries in non-democracies (Cotet and Tsui, 2013) or following oil price shocks if the oil is onshore (Nordvik, 2018). The role of arms imports specifically has not been explored however.

${ }^{2}$ Wezeman et al. (2011) suggest that in several cases arms imports may have helped governments legitimately maintain or restore stability. One example is in Chad, where a UN backed boost to the military in 2008, which included Chad's first combat aircraft, was instrumental in defeating rebels based in Sudan.
} 
repression. Blanton (1999) has indeed shown that arms imports are linked to human right violations in developing countries. A third reason is that arms purchases by governments may crowd out more development-friendly state spending. One example here is Fan et al. (2018), who showed that across countries military expenditures crowd out health expenditures.

The recent experience of Mozambique provides an illustrative anecdote on the link between newfound wealth and arms imports, as well as its potential consequences. After discovering enormous amounts of natural gas off its coast in 2009 - estimated at the time to be worth around 50 times its GDP in net present value terms (Arezki et al., 2017) - the country experienced an unprecedented growth spurt and a foreign investment boom (Toews and Vezina, 2017). It ended sharply five years later when a debt crisis hit. It turned out the government had borrowed too much, and illegally, to purchase military ships. This transaction worth hundreds of millions of dollars was made possible by loans worth around 2 billion dollars, or $12.5 \%$ of Mozambique's GDP. It inadvertently revealed cracks in the political system and that was enough to derail the entire economy, stopping foreign aid and investment (see Hill and Nhamire (2018)). Other cases of oil-for-arms episodes include Sudan's oil for guns deal with China (Herbst, 2008), Azerbaijan wasting the wealth from its post-2010 energy boom on vast amount of weapons (Altstadt and Menon, 2016), or the 1990s Angolagate scandal, which saw Angola's oil revenues exchanged against weapons from ex-Soviet countries (Economist, 2008). Figure 1 shows that, in those four countries, arms imports did surge after giant discoveries, in 2009-2011 in Mozambique, in 2003 in Sudan, in 2010 in Azerbaijan, and in 1996-1998 in Angola.

To examine the relationship between oil and gas discoveries and arms imports I combine data on discoveries from Horn (2011), updated by the World Bank, with arms imports data from the Stockholm International Peace Research Institute (SIPRI), as well as from the United Nations (COMTRADE). I focus on a panel covering 120 developing countries over 1990-2017, i.e. the post-Cold War years which also include the latest oil price boom that peaked in 2011 (Figure 4). I find that in the five years following a giant oil or gas discovery, 
Figure 1. Giant discoveries and arms imports
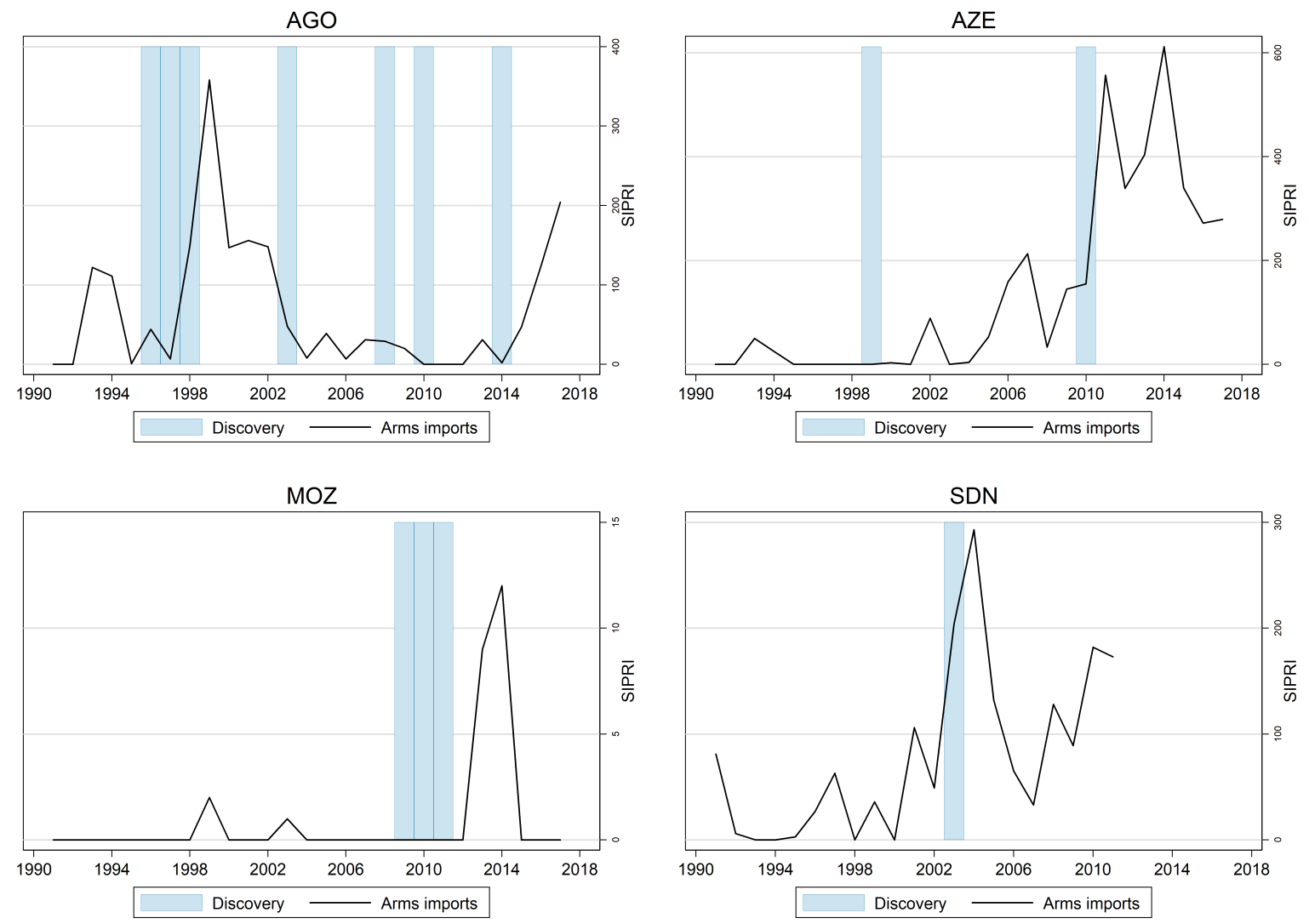

Notes: The arms imports data is from SIPRI. The data on giant discoveries is from Horn, M. and Myron K. 2011, Giant Oil and Gas Fields of the World, which was updated by the Africa Resource Future World Bank regional study group. 
arms imports increase by $25 \%$. The effect is even larger, i.e. $51 \%$, when the oil price is $\$ 80$ per barrel or higher. These estimates can be interpreted causally in a regression with country and year fixed effects as the timing of giant oil discoveries is unpredictable due to the uncertain nature of exploration. ${ }^{3}$ And while all imports also increase after discoveries - think new watches, trinkets, and shoes - the arms share of imports also increases, e.g. by $17 \%$ on average or by $27 \%$ when the oil price is around $\$ 80$. What's more, the arms imports share of GDP increases by around 30\% after giant discoveries. Across discovery countries, the average arms share of GDP was 0.5\% during 1990-2018. This share shoots up after discoveries. In Sudan for example, the arms imports share of GDP jumped from around $0.5 \%$ to more than $8 \%$ in 2008. In Equatorial Guinea, it reached around 5\% of GDP in 2003, 4 years after the giant discovery. In Azerbaijan, it went up to around $2.5 \%$ after the two discoveries in 1999 ad 2010. In Congo-Brazzaville, it shot up to above 3\% in 2013, the year of the discovery. On average I estimate that 4 years after a discovery, the arms imports share of GDP is 6 times larger than it was in the discovery year.

While the relationship between oil discoveries and arms imports hasn't been established before, there is a literature on the links between oil and arms more generally. The latter can help us understand the different reasons why we observe this arms imports surge after discoveries. The first explanation that may come to mind is that future oil producers may want to protect their resources from rebels or foreign invasion and hence lash out on sophisticated weapons. This was Mozambique's government justification for buying military speedboats. This explanation however hasn't been put forward much by the literature. Instead, the literature focuses mostly on supply-based explanations. Nisticò et al. (2018) for example argue that selling arms is a foreign policy tool to secure access to oil, as providing arms might reduce the risk of political instability in oil-rich countries. Nitzan and Bichler

\footnotetext{
${ }^{3}$ Giant discoveries of at least 500 million barrels of recoverable oil can be thought of as winning the jackpot when playing the exploration-drilling lottery. Previous studies have indeed suggested that the timing of giant oil discoveries is plausibly exogenous due to their unexpected nature (Arezki et al., 2017; Tsui, 2011; Lei and Michaels, 2014; Cavalcanti et al., 2019). The relationship between resource rents and arms imports on the other hand could be endogenous as a well-equipped military could be a condition to successful extraction, for example.
} 
(1995) calls it the weapondollar-petrodollar coalition. Khanna and Chapman (2010) suggest that the huge transfer of weapons to Persian Gulf countries during 1989-1999 might have been in order to keep access to a steady supply of oil. This would also fit with the oil-for-arms deal between China and Sudan mentioned in the introduction. Other researchers provide a more macroeconomic explanation. Chan (1980) and Snider (1984) suggest that expensive oil affects the supply of weapons, as oil-importing countries such as the US, UK, France, Germany, and Italy might be using arms exports to offset the cost of imported oil.

Another explanation might be that, when news of these giant discoveries break out, shady businessmen exploit new opportunities to siphon debt money. This is in line with what happened in Mozambique, where a Lebanese businessman convinced a handful of Mozambique government officials and dodgy Credit Suisse bankers to issue debt to purchase French military ships. It's also in line with the Angolagate scandal, when the son of the ex-French president was involved in a scheme where Soviet arms were purchased with the revenues of selling oil from Angola to France.

This paper adds to the resource curse literature by suggesting a new channel through which resources can unleash malign development forces. This new channel furthers our understanding of the oil and conflict relationship, e.g. (Lei and Michaels, 2014), by highlighting that discoveries might trigger large amount of arms imports. These arms imports may fuel future conflicts (Pamp et al., 2018), increase political repression (Blanton, 1999), and crowd out state spending on health, education, and infrastructure (e.g. Fan et al. (2018)). Conflicts and other anti-development forces may hence, in some cases, be an indirect consequence of balance-of-payment preferences in arms exporters (Chan, 1980; Snider, 1984) or of a handful of greedy businessmen. The import of arms may thus be one reason why oil-rich governments perpetuate the curse of oil.

The paper proceeds as follows. In section 2 I describe the data and my empirical strategy. In section 3 I present my results. Section 4 concludes. 


\section{DATA}

I use data on arms imports from two sources. The first is the Stockholm International Peace Research Institute (SIPRI). SIPRI is the most trusted source of data on international arms transfers. Since official statistics on arms trade may be patchy, as governments may wish to hide them, SIPRI has been tracking transfers of major weapons, such as aircraft, drones, rocket launchers, missiles, torpedoes, and reconnaissance satellites, using a variety of sources such as newspapers, annual reports of arms producing companies, blogs, defence white papers, and parliamentary records. It then uses known production costs to estimate the value of the military transfers and construct a trend-indicator value of arms imports. While this indicator does not provide information on the prices of arms transfers, it provides a real unit that allows to identify trends over time.

As a robustness check I also use official customs data from the United Nations, i.e. COMTRADE. I use reports from both importers and exporters to maximize the data coverage. I include all goods classified as firearms of war and ammunition, that is, section 95 of the SITC Revision 1 classification. This includes artillery weapons and all types of guns and bullets (note that SIPRI does not include small arms). I also include armoured fighting vehicles, warships and aircrafts using the 4-digit HS-classification codes 8710, 8802, and 8906, to include major weapons. I convert the raw data, in nominal US dollars, to constant 2010 US dollars, to focus on real changes in arms transfers.

Figure 2 shows that there is a strong correlation between the two measures of arms imports, both in 1990 and 2010. The two measures seem more in line in 2010 then in 1990. Also, COMTRADE seem to cover more imports, as per its wider definition. Overall, these two sources should provide relevant alternatives to capture countries' arms imports.

I use data on giant oil and gas discoveries from Horn (2011), which has been updated by the World Bank. Giant discoveries are those of at least 500 million barrels of recoverable oil equivalent. They are unlikely events and hence can be thought of plausibly exogenous due 
Figure 2. Arms trade data
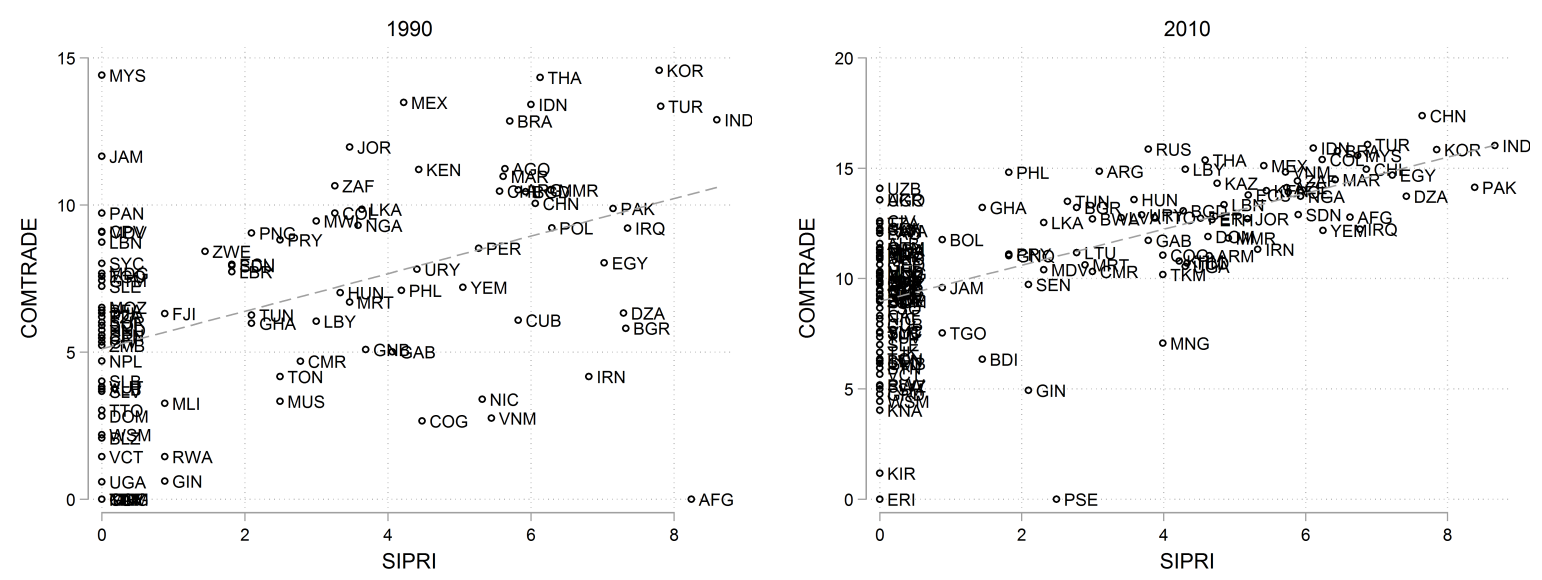

Source: SIPRI and COMTRADE.

to their unexpected nature. Figure 3 shows the number of such giant discoveries worldwide since 1990 as well as their geographic dispersion. There were around five giant discoveries per year over the period, but as much as 15 in 2008 when the oil price was close to its peak (Figure 4). While these are spread across five continents, Africa and Asia got the largest number of giant discoveries during this period.

A first look at the data suggest that arms imports do boom after discoveries. The event study graphs in Figure 5 suggest that in discovery countries, SIPRI imports are about 2.5 times larger in the five years after the discovery, compared to the 5 years before. COMTRADE data suggests that five years after the discovery arms imports may be as much as 10 times larger than in the five years before. Using the COMTRADE data we can also look at arms imports as a share of total imports or as a share of GDP. The data suggests that the arms share of total imports is around 6 times higher three years after the discovery. The arms share of GDP peaks 4 years after the discovery, when it is 6 times larger.

To explore further the relationship between giant discoveries and arms imports I use panel data covering 120 developing countries, defined as non-high income by the World Bank, i.e. those with an average GDP per capita below 12,055 2010 US dollars, over 1990-2017. This 
Figure 3. Giant discoveries 1990-2018

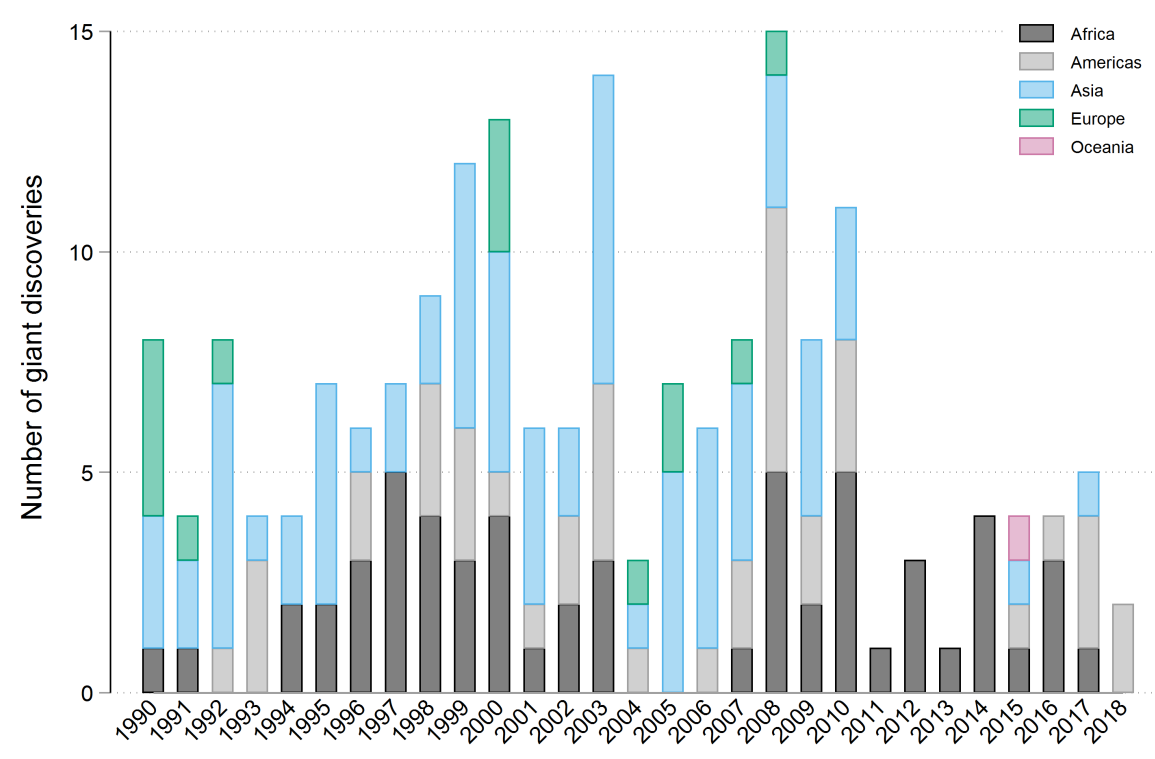

Source: Horn, M. and Myron K. 2011. Giant Oil and Gas Fields of the World. Updated by the Africa Resource Future WB regional study group.

Figure 4. Oil price in 2017 USD, 1990-2018

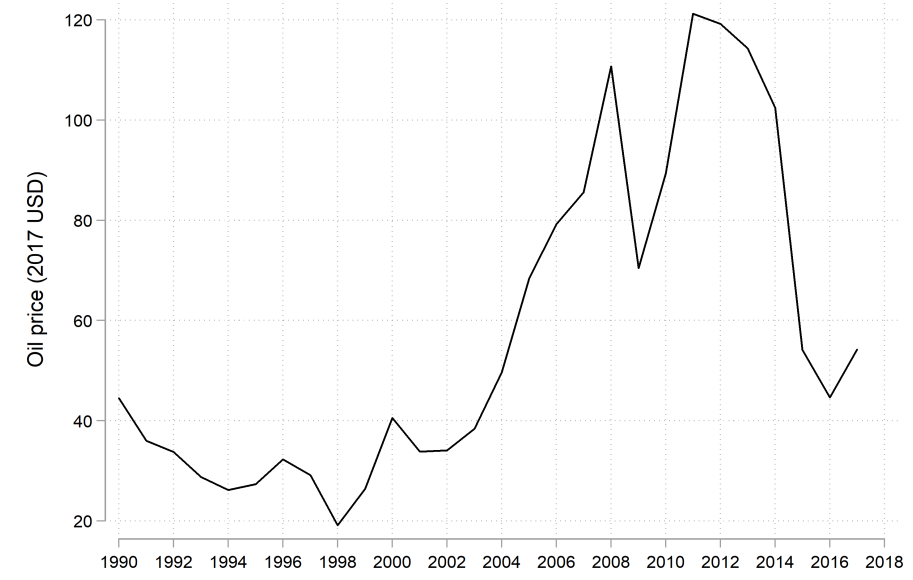

Source: Statistical Review of World Energy, bp. 
Figure 5. Arms imports after giant discoveries
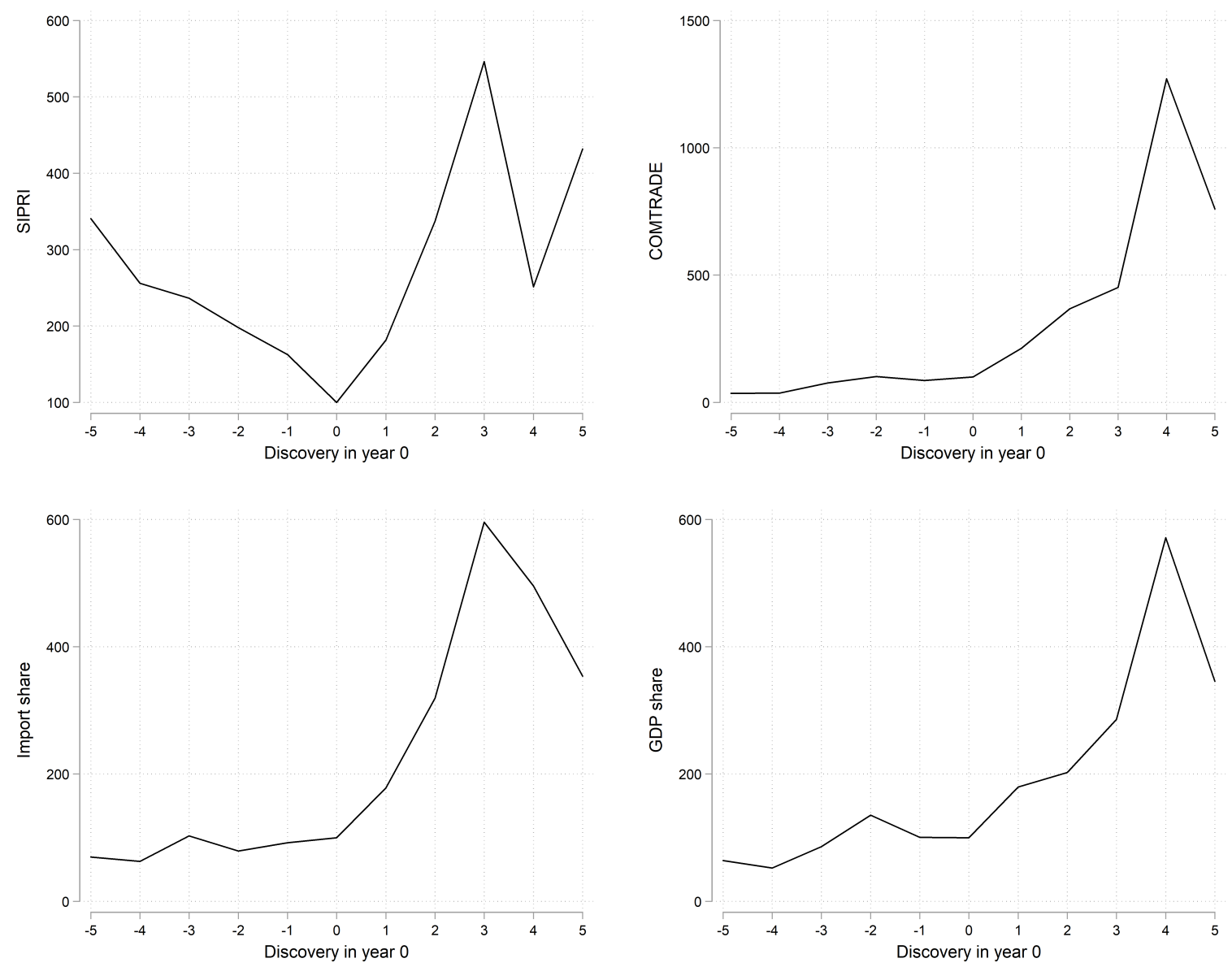

Notes: The figures show the levels of arms imports in the 10 years around all giant discoveries across countries. The scale is normalized so that arms imports $=100$ in the year of the discovery. Sources: Horn (2011), COMTRADE, SIPRI, World Development Indicators. 
period covers only post-Cold War years, as the Cold War had a large impact on arms trade patterns (e.g. Akerman and Seim (2014)), and it also covers the oil price boom of the 2000s. More precisely, I estimate the following regression:

$$
\text { Arms }_{i t}=\beta D_{i t 5}+\alpha_{i}+\sigma_{t}+\epsilon_{i t}
$$

where $A r m s_{i t}$ is total imports of arms in country $i$ in year $t$, and $D_{i t 5}$ is dummy equal to 1 in the year of the discovery and the five subsequent years. I use a five-year post-discovery period as this is less than the average delay between discovery and extraction (Arezki et

al. (2017) puts it at 7 years.). Country fixed effects $\left(\alpha_{i}\right)$ pick up factors that vary little year-on-year such as governance, year fixed effects $\left(\sigma_{t}\right)$ pick up global factors such as arms races. As mentioned above, giant discoveries can be thought of as plausibly exogenous due to their unexpected nature (Arezki et al., 2017; Tsui, 2011; Lei and Michaels, 2014; Cavalcanti et al., 2019). This allows me to interpret the $\beta$ coefficient as a causal effect. I discuss results in the next section.

\section{RESULTS}

Baseline results are in Table 1. It shows the effect of giant discoveries on arms imports based on SIPRI data (columns 1-2), COMTRADE data (columns 3-4), and on the arms share of total imports or GDP, based on COMTRADE and World Bank data (columns 5-8). While odd columns give the results to the baseline regression as described in the previous section, even columns show how robust the results are to the inclusion of an additional control variable, i.e. the number of previous giant discoveries. I include this control as a country which experiences a first giant discovery might not react the same way as a country which had many discoveries in the past, as Angola for example (see Figure 1).

I find a positive and statistically significant effect of giant discoveries on arms imports, using both SIPRI and COMTRADE data. The lower bound estimate suggests that in the five years after a giant discovery, arms imports are $25 \%$ larger $(\operatorname{asinh}(0.258))$. The arms 
Table 1: Dependent Variable: Arms imports

\begin{tabular}{lcccccccc}
\hline \hline & $(1)$ & $(2)$ & $(3)$ & $(4)$ & $(5)$ & $(6)$ & $(7)$ & $(8)$ \\
& SIPRI & SIPRI & COMTRADE & COMTRADE & $\begin{array}{c}(5) \\
\text { Import share }\end{array}$ & $\begin{array}{c}\text { Import share } \\
\text { GDP share }\end{array}$ & GDP share \\
\hline Discovery in past 5 years & $0.290^{* *}$ & $0.258^{* *}$ & $0.301^{* *}$ & $0.290^{* *}$ & 0.171 & 0.178 & $0.304^{* *}$ & $0.330^{* *}$ \\
& $(0.121)$ & $(0.121)$ & $(0.133)$ & $(0.132)$ & $(0.121)$ & $(0.121)$ & $(0.131)$ & $(0.131)$ \\
Nb of previous discoveries & & $0.143^{* *}$ & & 0.048 & & -0.029 & $(0.045)$ & $-0.102^{* *}$ \\
& & $(0.057)$ & & $(0.050)$ & & 3523 & 3436 & 3436 \\
\hline $\mathrm{N}$ & 3640 & 3640 & 3523 & 3523 & 3523 & $0.051)$ \\
$\mathrm{R}$-sq & 0.69 & 0.69 & 0.74 & 0.74 & 0.41 & 0.41 & 0.37 & 0.37 \\
\hline \hline
\end{tabular}

The dependent variable is in inverse hyperbolic sine. The regressions include country and year fixed effects. Robust standard errors in parenthesis, and * stands for statistical significance at the $10 \%$ level, ** at the $5 \%$ level and $* * *$ at the $1 \%$ percent level.

share of GDP increases by $30 \%$. The arms share of imports also increases, by $17 \%$, though the effect is not statistically significant here. This may be because in some countries total imports increase as well, as the demand for say manufacturing goods increases. ${ }^{4}$ Yet the large coefficient suggests that the increase in arms imports is larger than that of other imports on average.

In Table 2 I show the results of estimating the same regressions but on a restricted sample of countries, i.e. those countries which have experienced at least one giant discovery over the period of study. The idea here is that discovery countries in non-post-discovery years provide a more conservative counterfactual than countries without giant discoveries or even without oil exploration, which may be different from discovery countries in terms of arms imports in general. This robustness check confirms the baseline results and even suggests slightly larger effects. The lower bound estimate here suggests that arms imports increase by $31 \%$ in the five years following a giant discovery. The coefficient on the arms share of imports is now statistically significant, and suggests that the arms share of total imports increases by around $21 \%$. The effect on arms imports as a share of GDP remains stable around $30 \%$.

In Figure 6 I run the baseline regression of odd columns in Table 1 but using different

\footnotetext{
${ }^{4}$ Gollin et al. (2016) show that across 116 developing countries, imports of food and manufacturing, as a share of GDP, go up when natural resource exports increase.
} 
Table 2: Dependent Variable: Arms imports. Sample: Only discovery countries.

\begin{tabular}{lcccccccc}
\hline \hline & $(1)$ & $(2)$ & $(3)$ & $(4)$ & $(5)$ & $(6)$ & $(7)$ & $(8)$ \\
& SIPRI & SIPRI & COMTRADE & COMTRADE & Import share & Import share & GDP share & GDP share \\
\hline Discovery in past 5 years & $0.343^{* * *}$ & $0.360^{* * *}$ & $0.313^{* *}$ & $0.338^{* *}$ & 0.176 & $0.209^{*}$ & $0.299^{* *}$ & $0.332^{* *}$ \\
& $(0.118)$ & $(0.119)$ & $(0.133)$ & $(0.135)$ & $(0.122)$ & $(0.124)$ & $(0.131)$ & $(0.134)$ \\
Nb of previous discoveries & & -0.062 & & $-0.091^{*}$ & & $-0.121^{* *}$ & $-0.114^{* *}$ \\
& & $(0.057)$ & & $(0.054)$ & & $(0.049)$ & $(0.054)$ \\
\hline $\mathrm{N}$ & 1378 & 1378 & 1324 & 1324 & 1324 & 1324 & 1289 & 1289 \\
$\mathrm{R}$-sq & 0.67 & 0.67 & 0.69 & 0.69 & 0.35 & 0.35 & 0.31 & 0.31 \\
\hline
\end{tabular}

The dependent variable is in inverse hyperbolic sine. The regressions include country and year fixed effects. Robust standard errors in parenthesis, and * stands for statistical significance at the $10 \%$ level, $* *$ at the $5 \%$ level and ${ }^{* * *}$ at the $1 \%$ percent level.

post-discovery treatment periods. More precisely, I estimate six different regressions where $D_{i t}$ is a dummy equal to 1 in the year of the discovery only or also in the one, two, three, four or five subsequent years. While I find positive and significant effects across these different specifications, the 5-year period captures the largest effect. This is in line with arms imports occurring not necessarily right after but in any of the post-discovery years, before extraction happens. It's also in line with the event studies in Figure 5 which show arms imports surging mostly in the 3 to 5 years after the discoveries.

In Figure 7 I run the baseline regressions of odd columns in Table 2, i.e. using the sample of only discovery countries, but using dummies based on 200 placebo discoveries instead of the real post-discovery treatment periods. The placebo discoveries are generated by shuffling the discovery dummy either randomly across country-years (column 1 in Figure 7 ), across countries within years (column 2), or across years within countries (column 3). While I find that among 200 random placebo discoveries, some do have positive effects on arms imports (note that placebo discoveries here may coincide with real discoveries), overall the distribution is centered around zero. The effect of real discoveries, indicated by the dashed vertical line, suggest that we are only likely to find such effects by chance around $90 \%$ of the time, confirming the robustness of the results.

In Table 3 I examine how the effect of giant discoveries on arms imports depend on the oil price. If one reason for the arms transfers is to offset expensive oil, we should expect 
Figure 6. The jumps in arms imports after discoveries
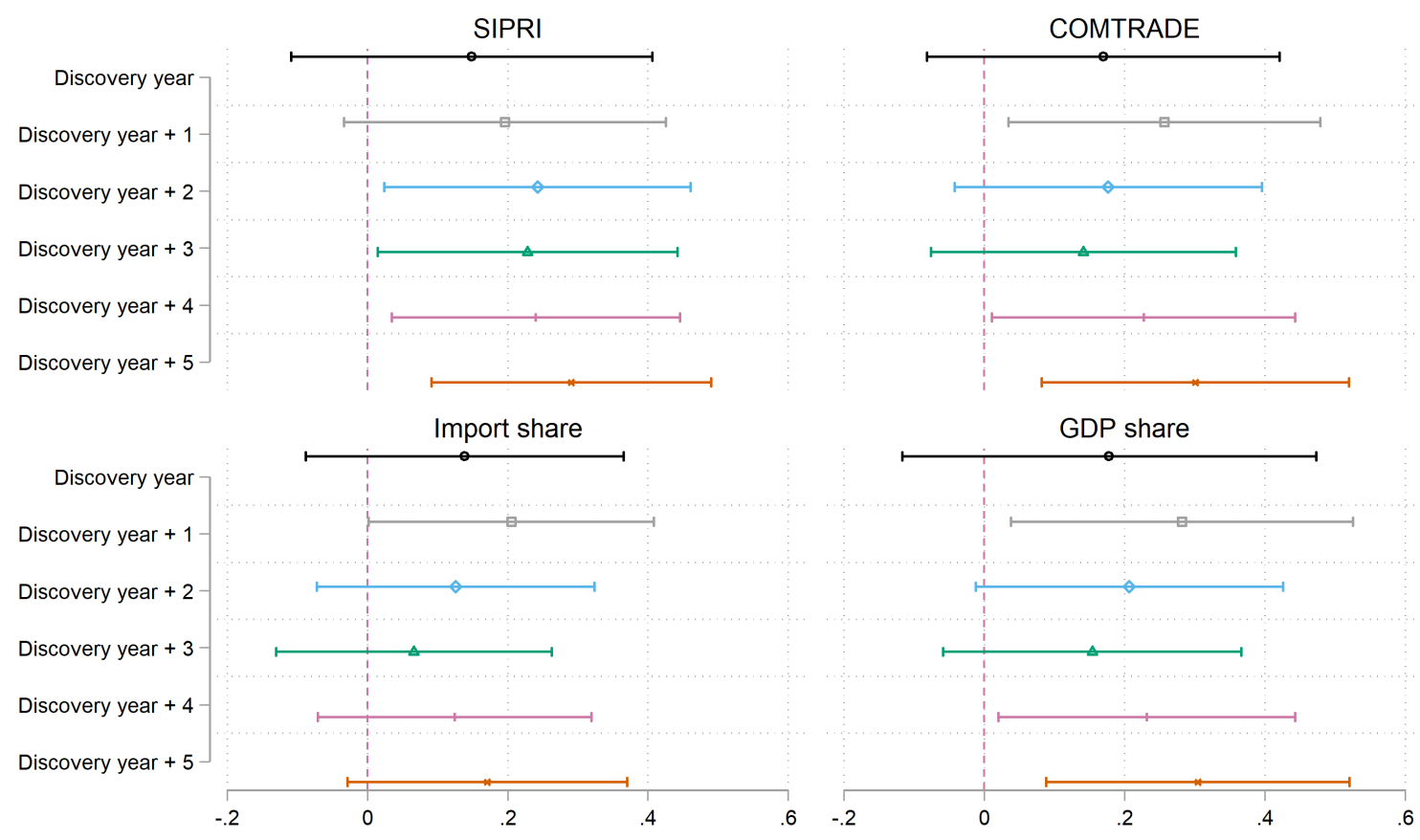

Notes: The coefficients show the increase in arms imports after giant discovery, over different horizons. It shows the results of regressions akin to that of odd columns in Table 1 but using different post-discovery treatment periods. Each panel shows the results of six different regressions where $D_{i t}$ is a dummy equal to 1 in the year of the discovery only or also in the one, two, three, four or five subsequent years. The figure thus show how sensitive my baseline results are to different post-discovery treatment periods. 
Figure 7. The effect of real vs. placebo discoveries
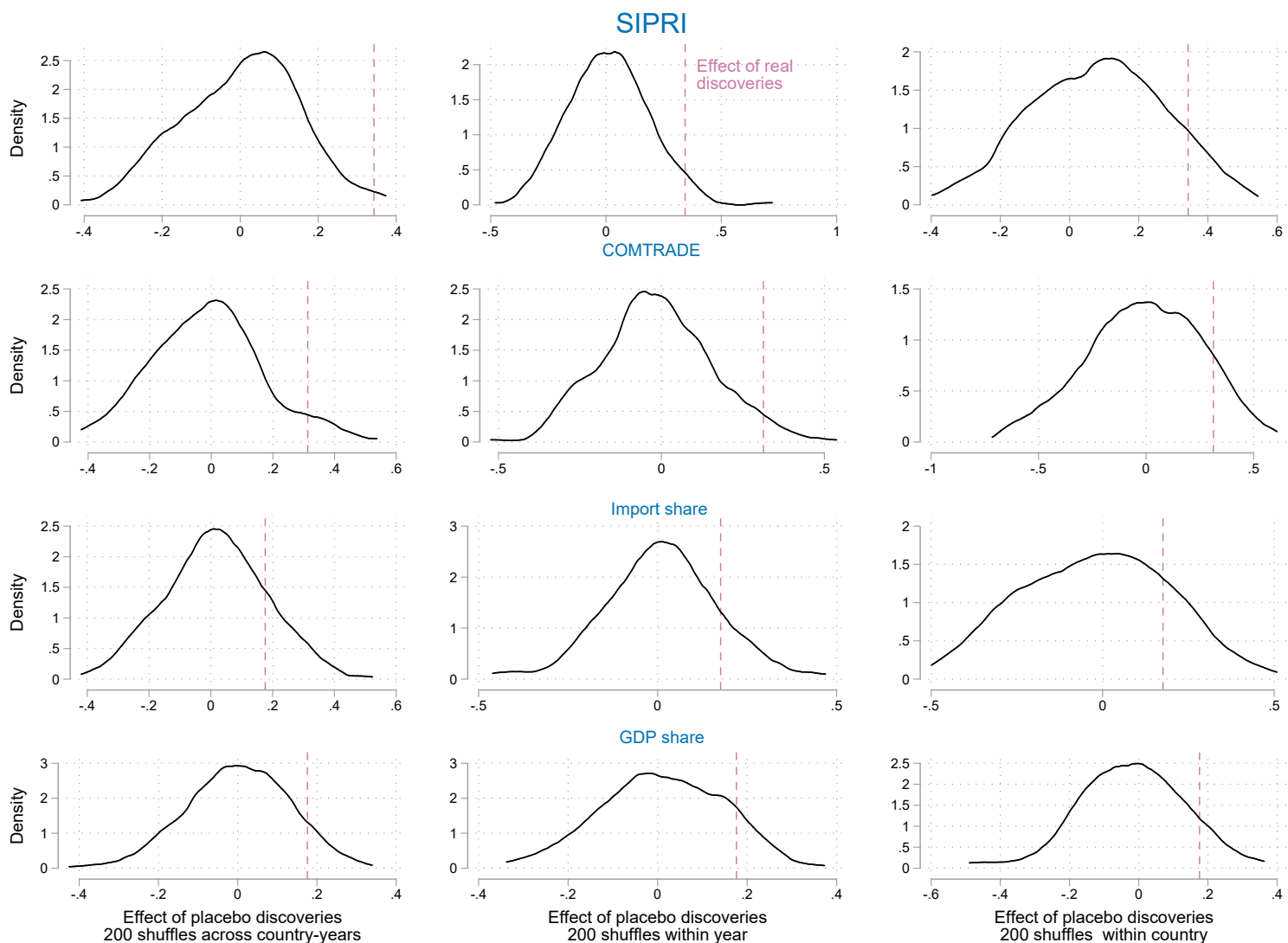

Notes: The figures show the distributions of the effects of 200 placebo discoveries on arms imports based on SIPRI (row 1), COMTRADE (row 2), on the arms share of imports (row 3), and on the arms share of GDP (row 4). The 200 placebo discoveries are generated by shuffling the discovery variable across country-years (column 1), across countries within years (column 2 ), and across years within country (column 3 ). These figures are generated by estimating 200 regressions akin to that of columns $1,3,5$, and 7 in Table 2, using the sample of only discovery countries. The vertical line shows the effect of real discoveries as reported in columns $1,3,5$, and 7 in Table 2. 
them to be more likely in times of high oil prices, i.e. around 2007-2014 (see Figure 4). In these times discoveries are also more likely to attract the attention of businessmen and bankers, as the lure of easy money from arranging large arms transfers is strongest. In these regressions the oil price is centred around $\$ 80$. The coefficient on the discovery dummy thus gives the effect of a discovery when the price of a barrel of oil is $\$ 80$, and the coefficient on its interaction with the oil price variable shows how the effect varies with the oil price. The lower bound estimate here suggests that when a barrel costs $\$ 80$, a giant discovery increases arms imports by $51 \%$ and the arms share of imports by $27 \%$. The effect is smaller when the oil price is low and higher when the price is high. The difference in effects across high and low prices is statistically significant. The variation in effects is illustrated in the top left panel of Figure 8. The discovery effect is positive and significant only when the oil price is above $\$ 40$, and peaks at $65 \%$ when the oil price is above $\$ 100$.

The two bottom panels in Figure 8 show how the discovery effect on arms imports varies with the level of democracy and when the head of the executive in the importing country is a military officer. Given the role of governments and corrupt businessmen in facilitating such arms deals we could have expected the lack of democratic accountability to accentuate the discovery effect on arms deals. This is not what the results suggest. Instead we find a positive and significant effect only in the most democratic countries (these results are similar using the World Governance Indicators' measure of corruption). This may be because a minimum threshold of state capacity is required to generate revenues from the oil find. These interactions are not statistically significant however, and there might not be much relevant difference in institutional quality across countries in the sample. As for the role of military heads of state, the results are different whether I use SIPRI or COMTRADE data. The latter suggests that discoveries trigger arms imports only in countries where the head is a military officer, while SIPRI data suggests the opposite. I prefer not to make any conclusions about the role of military heads here.

In Tables 4 and 5 I check if giant discoveries trigger arms imports from all or only from 
Figure 8. Heterogeneity
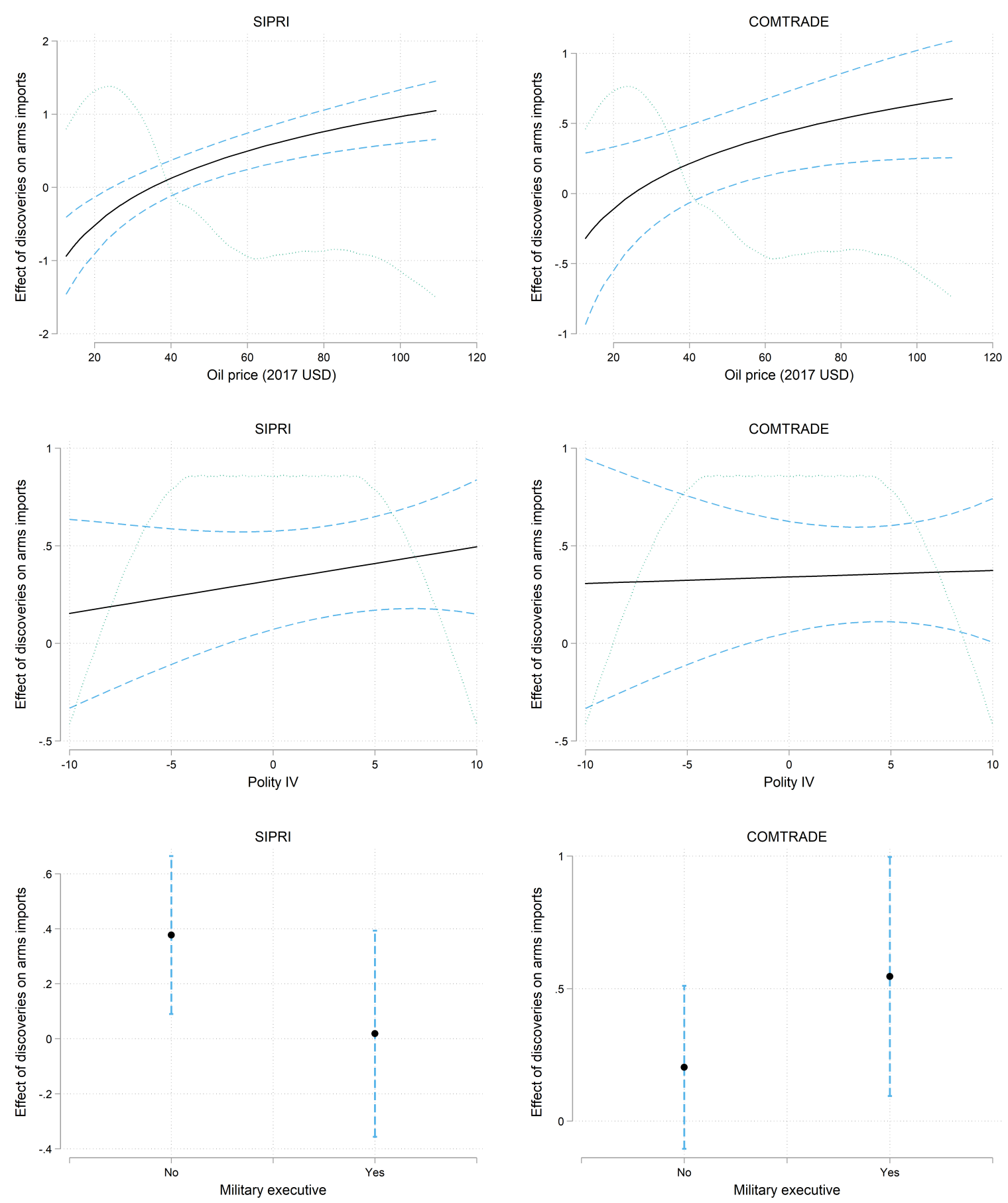

Notes: The oil price is in 2017 USD and is from BP. Polity IV is an index that measures the type of governance, and goes from -10 for autocracies to 10 for democracies. The Military variable is a dummy equal to 1 if the country's Chief Executive is a military officer, and is taken from the IDB's Database of Political Institutions 2015. 
Table 3: Dependent Variable: Arms imports. Add-on: interaction with the oil price.

\begin{tabular}{lcccccccc}
\hline \hline & $(1)$ & $(2)$ & $(3)$ & $(4)$ & $(5)$ & $(6)$ & $(7)$ & $(8)$ \\
& SIPRI & SIPRI & COMTRADE & COMTRADE & $\begin{array}{c}(7) \\
\text { Import share }\end{array}$ & $\begin{array}{c}\text { Import share } \\
\text { GDP share }\end{array}$ & $\begin{array}{c}\text { GDP share } \\
\text { COMP }\end{array}$ \\
\hline Discovery in past 5 years & $0.761^{* * *}$ & $0.809^{* * *}$ & $0.533^{* * *}$ & $0.603^{* * *}$ & $0.273^{*}$ & $0.404^{* *}$ & 0.184 & $0.297^{*}$ \\
& $(0.155)$ & $(0.180)$ & $(0.166)$ & $(0.187)$ & $(0.152)$ & $(0.169)$ & $(0.159)$ & $(0.170)$ \\
$\times$ Oil price & $0.919^{* * *}$ & $0.994^{* * *}$ & $0.460^{* *}$ & $0.575^{* *}$ & 0.202 & $0.415^{*}$ & -0.246 & -0.062 \\
& $(0.184)$ & $(0.235)$ & $(0.204)$ & $(0.262)$ & $(0.182)$ & $(0.230)$ & $(0.203)$ & $(0.247)$ \\
Nb of previous discoveries & & -0.037 & & -0.056 & & $-0.105^{*}$ & $(0.059)$ & -0.091 \\
& & $(0.071)$ & & $(0.067)$ & & 3523 & 3436 & 3436 \\
\hline $\mathrm{N}$ & 3640 & 3640 & 3523 & 3523 & 3523 & $0.062)$ \\
$\mathrm{R}$-sq & 0.69 & 0.69 & 0.74 & 0.74 & 0.41 & 0.41 & 0.37 & 0.37 \\
\hline \hline
\end{tabular}

The dependent variable is in inverse hyperbolic sine. The log of oil price is centered around $\$ 80$. The regressions include country and year fixed effects. Robust standard errors in parenthesis, and $*$ stands for statistical significance at the $10 \%$ level, ${ }^{* *}$ at the $5 \%$ level and $* * *$ at the $1 \%$ percent level.

some countries among the major arms exporters. I estimate both the baseline model and the model where the discovery dummy is interacted with the oil price. According to SIPRI data, arms imports from the US, Russia, Germany, France, and China account for around $75 \%$ of all imports during the whole study period, with a long list of other countries accounting for the remaining 25\%. I thus check if discoveries trigger arms imports from these large arms exporters in particular. The first surprising result is that arms imports from the US, the largest arms exporter in the world, do not react at all to giant discoveries. This is true across specifications and datasets. For other countries the results are different whether we look at COMTRADE or SIPRI data. Using COMTRADE data I find arms imports from China to be particular responsive to giant discoveries, while arms from France and Germany react strongly to discoveries but only in times of high oil prices. SIPRI data on the other hand suggest that it is Russian arms that react most to giant discoveries. Overall these results suggest that different discovery countries might import arms from different countries.

In Table 6 I look at how different type of discoveries affect arms imports. I focus on three dimensions, i.e. oil vs gas, onshore vs offshore, and by field distance to the nearest border. The top panel shows results when I include separate dummies for oil and gas discoveries on the right hand side. While the results using SIPRI data suggest that both oil and gas discoveries lead to higher arms imports, the results using COMTRADE data suggests only 
Table 4: Dependent Variable: Arms imports - COMTRADE

\begin{tabular}{lccccccc}
\hline \hline & $(1)$ & $(2)$ & $(3)$ & $(4)$ & $(5)$ & $(6)$ & $(7)$ \\
& All & USA & RUS & CHN & DEU & FRA & RoW \\
\hline Discovery in past 5 years & $0.301^{* *}$ & -0.146 & 0.222 & $0.343^{*}$ & 0.187 & 0.209 & $0.588^{* * *}$ \\
& $(0.133)$ & $(0.208)$ & $(0.213)$ & $(0.191)$ & $(0.181)$ & $(0.253)$ & $(0.144)$ \\
\hline $\mathrm{N}$ & 3523 & 3523 & 3523 & 3523 & 3523 & 3523 & 3523 \\
$\mathrm{R}$-sq & 0.74 & 0.72 & 0.57 & 0.61 & 0.74 & 0.66 & 0.73 \\
\hline \hline \hline & $(1)$ & $(2)$ & $(3)$ & $(4)$ & $(5)$ & $(6)$ & $(7)$ \\
& All & USA & RUS & CHN & DEU & FRA & RoW \\
\hline Discovery in past 5 years & $0.533^{* * *}$ & -0.059 & 0.037 & $0.484^{* *}$ & $0.827^{* * *}$ & $0.799^{* *}$ & $0.847^{* * *}$ \\
& $(0.166)$ & $(0.249)$ & $(0.278)$ & $(0.239)$ & $(0.262)$ & $(0.344)$ & $(0.171)$ \\
$\times$ Oil price & $0.460^{* *}$ & 0.171 & -0.367 & 0.280 & $1.271^{* * *}$ & $1.173^{* * *}$ & $0.516^{* *}$ \\
& $(0.204)$ & $(0.299)$ & $(0.363)$ & $(0.286)$ & $(0.303)$ & $(0.388)$ & $(0.202)$ \\
\hline $\mathrm{N}$ & 3523 & 3523 & 3523 & 3523 & 3523 & 3523 & 3523 \\
R-sq & 0.74 & 0.72 & 0.57 & 0.61 & 0.74 & 0.66 & 0.73 \\
\hline \hline
\end{tabular}

The dependent variable is in inverse hyperbolic sine. The regressions include country and year fixed effects. Robust standard errors in parenthesis, and * stands for statistical significance at the $10 \%$ level, $* *$ at the $5 \%$ level and ${ }^{* * *}$ at the $1 \%$ percent level.

Table 5: Dependent Variable: Arms imports - SIPRI

\begin{tabular}{lccccccc}
\hline \hline & $(1)$ & $(2)$ & $(3)$ & $(4)$ & $(5)$ & $(6)$ & $(7)$ \\
& All & USA & RUS & CHN & DEU & FRA & RoW \\
\hline Discovery in past 5 years & $0.290^{* *}$ & -0.005 & 0.128 & -0.001 & 0.036 & 0.015 & -0.056 \\
& $(0.121)$ & $(0.092)$ & $(0.123)$ & $(0.090)$ & $(0.076)$ & $(0.074)$ & $(0.127)$ \\
\hline $\mathrm{N}$ & 3640 & 3640 & 3640 & 3640 & 3640 & 3640 & 3640 \\
$\mathrm{R}$-sq & 0.69 & 0.70 & 0.55 & 0.59 & 0.58 & 0.61 & 0.57 \\
\hline \hline \hline & $(1)$ & $(2)$ & $(3)$ & $(4)$ & $(5)$ & $(6)$ & $(7)$ \\
& All & USA & RUS & CHN & DEU & FRA & RoW \\
\hline Discovery in past 5 years & $0.761^{* * *}$ & 0.079 & $0.605^{* * *}$ & 0.053 & $0.169^{*}$ & 0.104 & $0.429^{* * *}$ \\
& $(0.155)$ & $(0.102)$ & $(0.161)$ & $(0.112)$ & $(0.088)$ & $(0.086)$ & $(0.153)$ \\
$\times$ Oil price & $0.919^{* * *}$ & 0.164 & $0.932^{* * *}$ & 0.106 & $0.260^{* *}$ & $0.173^{*}$ & $0.947^{* * *}$ \\
& $(0.184)$ & $(0.121)$ & $(0.196)$ & $(0.118)$ & $(0.112)$ & $(0.103)$ & $(0.191)$ \\
\hline $\mathrm{N}$ & 3640 & 3640 & 3640 & 3640 & 3640 & 3640 & 3640 \\
R-sq & 0.69 & 0.70 & 0.56 & 0.59 & 0.58 & 0.61 & 0.57 \\
\hline \hline The depp
\end{tabular}

The dependent variable is in inverse hyperbolic sine. The regressions include country and year fixed effects. Robust standard errors in parenthesis, and * stands for statistical significance at the $10 \%$ level, ${ }^{* *}$ at the $5 \%$ level and ${ }^{* * *}$ at the $1 \%$ percent level. 
gas discoveries are associated with larger arms imports. These are not statistically significant results however. This may be because, while both oil and gas discoveries probably can trigger arms imports, identifying their average affects separately requires a larger time period.

The second panel suggests that it might only be offshore discoveries that trigger arms imports. While this result is in line with the Angola and Mozambique anecdotes, it does not appear to be in line with the evidence from Nordvik (2018) who suggested that while onshore oil motivates military build-ups, offshore oil does not. It also goes against the idea that arms imports are to be used to protect onshore fields.

The lower panel looks at how the discoveries' distance to the border affect their impact on trade. The idea here is based on Caselli et al. (2015) who suggested that bordering countries are more likely to engage in conflict when one of the countries has resources near the border. Countries may thus be more likely to import arms after discoveries closer to the border if the arms imports are linked to potential interstate conflict. Here I interact the discovery dummy with a measure of the country's discovery's minimum distance to the border. Since this distance does not exist for countries with no discoveries, I focus only on discovery countries here. Furthermore, since this distance exist only for years with a discovery, I aggregate it at the country level by taking the minimum of the minimum distances of the country's discoveries. The coefficient on the discovery dummy's interaction with MinDist therefore captures whether discoveries have a larger effect on arms imports in countries where discoveries are closer to the border. I take the minimum rather than the average distances as only one discovery near the border in a multi-discovery country may have as much effect as one in a single-discovery country. Results suggest no significant interaction however, and COMTRADE data suggests that discoveries far away from borders might have more of an effect, if any at all. Overall there does not seem to be any clear pattern suggesting that certain types of discoveries matter more than others. 
Table 6: How the type of discovery affects arms imports

\begin{tabular}{|c|c|c|c|c|}
\hline \multicolumn{5}{|c|}{$(2)$} \\
\hline & IPRI & OMTRADE I & Import share & GDP share \\
\hline \multirow[t]{2}{*}{ Oil } & .102 & -0.027 & -0.109 & -0.064 \\
\hline & $.197)$ & $(0.220)$ & $(0.195)$ & $(0.214)$ \\
\hline \multirow[t]{2}{*}{ Gas } & .183 & 0.235 & 0.128 & $0.339^{*}$ \\
\hline & $.150)$ & $(0.195)$ & $(0.175)$ & $(0.199)$ \\
\hline $\mathrm{N}$ & 2800 & 2697 & 2697 & 2618 \\
\hline R-sq & 0.71 & 0.74 & 0.43 & 0.37 \\
\hline \multicolumn{5}{|c|}{ Onshore vs. offshore } \\
\hline & (1) & $(2)$ & $(3)$ & (4) \\
\hline & SIPRI & COMTRADE & Import share & GDP share \\
\hline \multirow[t]{2}{*}{ Onshore } & 0.026 & $-0.539^{* *}$ & $-0.567^{* *}$ & $-0.416^{*}$ \\
\hline & $(0.202)$ & $(0.244)$ & $(0.222)$ & $(0.246)$ \\
\hline \multirow[t]{2}{*}{ Offshore } & $0.345^{* *}$ & $0.832^{* * *}$ & $0.633^{* * *}$ & $0.723^{* * *}$ \\
\hline & $(0.169)$ & $(0.174)$ & $(0.161)$ & $(0.189)$ \\
\hline $\mathrm{N}$ & 2800 & 2697 & 2697 & 2618 \\
\hline R-sq & 0.71 & 0.74 & 0.43 & 0.37 \\
\hline \multicolumn{5}{|c|}{ Distance to nearest border } \\
\hline \multicolumn{2}{|r|}{ (1) } & $(2)$ & $(3)$ & (4) \\
\hline \multicolumn{2}{|r|}{ SIPRI } & I COMTRADE & Import share & GDP share \\
\hline \multirow[t]{2}{*}{ Discovery } & 0.075 & -1.787 & -0.925 & 0.488 \\
\hline & $(1.175)$ & $(1.629)$ & $(1.464)$ & $(1.471)$ \\
\hline \multirow[t]{2}{*}{$\times$ Min Dist } & 0.007 & 0.402 & 0.206 & -0.040 \\
\hline & $(0.228)$ & $(0.309)$ & $(0.278)$ & $(0.275)$ \\
\hline $\mathrm{N}$ & 960 & 917 & 917 & 883 \\
\hline R-sq & 0.69 & 0.69 & 0.40 & 0.32 \\
\hline
\end{tabular}

Notes: The dependent variable is in inverse hyperbolic sine. Discovery dummies are for the past 5 years. Min Dist is the log of the country minimum of the country's discoveries' minimum distance to the nearest border. Period limited to 1990-2010 due to data availability. The regressions include country and year fixed effects. Robust standard errors in parenthesis, and * stands for statistical significance at the $10 \%$ level, ${ }^{* *}$ at the $5 \%$ level and ${ }^{* * *}$ at the $1 \%$ percent level. 


\section{CONCLUSION}

In this paper I have shown that arms imports increase by about $25 \%$ in the 5 years after a giant discovery. This effect is even larger, at around $51 \%$, if the oil price high, i.e. at $\$ 80$ per barrel. As a share of GDP, arms imports increase by around $30 \%$ in the 5 years after a giant discovery. I suggest that this relationship may be due to newly oil-rich countries wanting to protect their resources from rebels or foreign invasion, or to arms exporters using arms to offset pricey oil, or to oil-dependent countries seeking to secure future oil supply and contain the risk of instabilities in a future oil supplier. I also suggest, based on the anecdotes of Mozambique and Angola, that an alternative mechanism is shady businessmen exploiting these opportunities to siphon debt money made available by the new discoveries.

This paper adds to our understanding of the resource curse by suggesting a new channel through which resources can hinder development. The purchase of arms may indeed explain why growth in newly oil-rich countries often fails to materialize. Public money could be spent on health, education, and infrastructure instead of arms. This effect of discoveries on arms imports also adds to our understanding of the relationship between oil and conflict as arms imports may fuel future conflicts (Pamp et al., 2018) as well as political repression (Blanton, 1999). This anti-development spending choice and its consequence on conflict may be an indirect consequence of balance-of-payment preferences in arms exporters (Chan, 1980; Snider, 1984) or of a handful of greedy businessmen. The import of arms may thus be one reason why oil-rich governments perpetuate the curse of oil. 


\section{References}

Akerman, Anders and Anna Larsson Seim, "The global arms trade network 1950-2007," Journal of Comparative Economics, 2014, 42 (3), 535 - 551.

Altstadt, Audrey L. and Rajan Menon, "Unfrozen Conflict in Nagorno-Karabakh," Foreign Affairs, 2016.

Arezki, Rabah, Valerie A. Ramey, and Liugang Sheng, "News Shocks in Open Economies: Evidence from Giant Oil Discoveries*," The Quarterly Journal of Economics, 2017, $132(1), 103$.

Blanton, Shannon Lindsey, "Instruments of security or tools of repression? Arms imports and human rights conditions in developing countries," Journal of Peace Research, 1999, $36(2), 233-244$.

Caselli, Francesco, Massimo Morelli, and Dominic Rohner, "The Geography of Interstate Resource Wars," The Quarterly Journal of Economics, 2015, 130 (1), 267-315.

Cavalcanti, Tiago, Daniel Da Mata, and Frederik Toscani, "Winning the oil lottery: the impact of natural resource extraction on growth," Journal of Economic Growth, Feb 2019.

Chan, Steve, "The Consequences of Expensive Oil on Arms Transfers," Journal of Peace Research, 1980, 17 (3), 235-246.

Cotet, Anca M and Kevin K Tsui, "Oil and conflict: what does the cross country evidence really show?," American Economic Journal: Macroeconomics, 2013, 5 (1), 49-80.

Craft, Cassady and Joseph P Smaldone, "The arms trade and the incidence of political violence in sub-Saharan Africa, 1967-97," Journal of Peace Research, 2002, 39 (6), 693-710. 
Cust, James Frederick and David Mihalyi, "Evidence for a presource curse ? oil discoveries, elevated expectations, and growth disappointments," Policy Research Working Paper Series 8140, The World Bank July 2017.

Economist, The, "Angola-gate," The Economist, 2008.

Fan, HongLi, Wei Liu, and Peter C. Coyte, "Do Military Expenditures Crowd-out Health Expenditures? Evidence from around the World, 2000-2013," Defence and Peace Economics, 2018, 29 (7), 766-779.

Gollin, Douglas, Remi Jedwab, and Dietrich Vollrath, "Urbanization with and without industrialization," Journal of Economic Growth, 2016, 21 (1), 35-70.

Herbst, Moira, "Oil for China, Guns for Darfur," Bloomberg, 2008.

Hill, Matthew and Borges Nhamire, "IMF expects Mozambique to Default on Foreign Debt Until 2023," Bloomberg, 2018.

Hirshleifer, Jack, "The macrotechnology of conflict," Journal of Conflict Resolution, 2000, $44(6), 773-792$.

Horn, (Mike) Myron K., "Giant Oil and Gas Fields of the World," http://www.datapages.com/AssociatedWebsites/GISOpenFiles/HornGiantFields.aspx, 2011.

Khanna, Neha and Duane Chapman, "Guns and oil: An analysis of conventional weapons trade in the post-cold war era," Economic Inquiry, 2010, 48 (2), 434-459.

Lei, Yu-Hsiang and Guy Michaels, "Do giant oilfield discoveries fuel internal armed conflicts?," Journal of Development Economics, 2014, 110 (C), 139-157.

Nisticò, Roberto, Claudio Deiana, and Vincenzo Bove, "Global arms trade and oil dependence," Journal of Law Economics and Organization, 02 2018, 34. 
Nitzan, Jonathan and Shimshon Bichler, "Bringing capital accumulation back in: The weapondollar-petrodollar coalition-military contractors, oil companies and middle east 'energy conflicts'," Review of International Political Economy, 1995, 2 (3), 446-515.

Nordvik, Frode Martin, "Does Oil Promote or Prevent Coups? The Answer is Yes," The Economic Journal, 2018, $0(0)$.

Pamp, Oliver, Lukas Rudolph, Paul W Thurner, Andreas Mehltretter, and Simon Primus, "The build-up of coercive capacities: Arms imports and the outbreak of violent intrastate conflicts," Journal of Peace Research, 2018, 55 (4), 430-444.

Ross, M. L., The Oil Curse: How Petroleum Wealth Shapes the Development of Nations, Princeton University Press, 2012.

Sachs, Jeffrey D. and Andrew M. Warner, "The curse of natural resources," European Economic Review, May 2001, 45 (4-6), 827-838.

Smith, Brock and Samuel Wills, "Left in the Dark? Oil and Rural Poverty," Journal of the Association of Environmental and Resource Economists, 2018, 5 (4), 865-904.

Snider, Lewis W., "Arms Exports for Oil Imports?: The Test of a Nonlinear Model," Journal of Conflict Resolution, 1984, 28 (4), 665-700.

Toews, Gerhard and Pierre-Louis Vezina, "Resource discoveries and FDI bonanzas; An illustration from Mozambique," Technical Report 2017.

Tsui, Kevin K., "More Oil, Less Democracy: Evidence from Worldwide Crude Oil Discoveries," Economic Journal, March 2011, 121 (551), 89-115.

van der Ploeg, Frederick, "Natural Resources: Curse or Blessing?," Journal of Economic Literature, June 2011, 49 (2), 366-420.

Venables, Anthony J., "Using Natural Resources for Development: Why Has It Proven So Difficult?," Journal of Economic Perspectives, Winter 2016, 30 (1), 161-84. 
Wezeman, Pieter D., Siemon T. Wezeman, and Lcuie Beraud-Sudreau, "Arms Flows to Sub-Saharan Africa," Technical Report, Stockholm International Peace Research Institute 2011. 